\title{
Frequency of Congenital Anomalies in the Brazilian Midwest and the Association with Maternal Risk Factors: Case-control Study
}

\section{Frequência das anomalias congênitas no centro-oeste brasileiro e a associação com fatores de risco materno: estudo caso- controle}

\author{
Carolina Leão de Moraes ${ }^{10}$ Natália Cruz e Melo ${ }^{2}$ Waldemar Naves do Amaral $^{10}$ \\ ${ }^{1}$ Faculty of Medicine, Department of Obstetrics and Gynecology, Hospital \\ das Clínicas, Universidade Federal de Goiás, Goiânia, GO, Brazil \\ Address for correspondence Carolina Leão de Moraes, MSc, \\ Universidade Federal de Goiás, Goiânia, GO, Brasil \\ 2 Escola Paulista de Medicina, Universidade Federal de São Paulo, SP, \\ Brazil
}

Rev Bras Ginecol Obstet 2020;42(4):188-193.

Abstract

Keywords
- congenital anomalies
- ultrasound
- prenatal
- prenatal diagnosis
- risk factors
Resumo

Objective To evaluate the frequency of structural congenital anomalies (CAs) in the midwest of Brazil and its association with maternal risk factors.

Methods This was a prospective, observational, case-control study based on a hospital population. Pregnant women attended at a fetal medicine service in Brazil were analyzed in the period from October 2014 to February 2016.A total of 357 pregnant women were included, 223 of whom had fetuses with structural anomalies (group case), and 134 of whom had structurally normal fetuses (control group). The clinical history was made previous to prenatal consultation, and the diagnosis of the structural CA was performed through ultrasound.

Results A frequency of $64.27 \%(n=223)$ of pregnant women with fetuses with structural anomalies was observed. The most frequent structural CAs were those of the central nervous system (30.94\%), followed by anomalies of the genitourinary system (23.80\%), and, finally, by multiple CAs (16.60\%). The background of previous children with CAs (odds ratio $[\mathrm{OR}]: 3.85 ; p=0.022$ ), family history (OR: $6.03 ; p=<0.001)$, and consanguinity between the progenitors (OR: $4.43 ; p=0.034$ ) influenced the occurrence of structural CA. Conclusion The most frequent CAs are those of the central nervous system, followed by those of the genitourinary system, and then multiple anomalies. The maternal risk factors that may have influenced the occurrence of structural CA were previous children with CA, family history, and consanguinity among the parents.

Objetivo Avaliar a frequência de anomalias congênitas (ACs) estruturais no centrooeste brasileiro e a associação com fatores de risco maternos.

Métodos Estudo prospectivo, observacional, caso-controle, baseado em uma população hospitalar. Foram analisadas gestantes atendidas em um serviço de medicina received

March 27, 2019

accepted

March 2, 2020
DOI https://doi.org/

10.1055/s-0040-1709692. ISSN $0100-7203$.
Copyright $\odot 2020$ by Thieme Revinter

Publicações Ltda, Rio de Janeiro, Brazil
License terms

(c) (1) 


\section{Palavras-chave \\ - anomalias congênitas \\ - ultrassom \\ - pré-natal \\ - diagnóstico pré- natal \\ - fatores de risco}

fetal no Brasil, no período de outubro de 2014 a fevereiro de 2016. Foram analisadas 357 gestantes, dentre as quais 223 tiveram fetos com ACs estruturais (grupo controle) e 134 tiveram fetos estruturalmente normais (grupo controle). A história clínica foi feita antes da consulta de pré-natal, e o diagnóstico da AC estrutural foi realizado por ultrassonografia.

Resultados Observou-se uma frequência de $64,27 \%(n=223)$ de gestantes com fetos com ACs estruturais. As ACs estruturais mais frequentes foram as do sistema nervoso central (30,94\%), seguidas das anomalias do sistema gênito-urinário (23,80\%), e, por fim, das ACs múltiplas (16,60\%). Antecedentes de crianças com AC (razão de probabiliade [RP]: 3,$85 ; p=0,022$ ), antecedentes familiares (RP: 6,$03 ; p=<0,001$ ), e consanguinidade entre os grupos progenitores (RP: 4,$43 ; p=0,034$ ) influenciaram a ocorrência de AC estrutural.

Conclusão As ACs mais frequentes foram as do sistema nervoso central, as do sistema gênito-urinário, e as ACs múltiplas. Os fatores de risco maternos que podem ter influenciado a ocorrência de $A C$ estrutural foram antecedentes de crianças com $A C$, história familiar, e a consanguinidade entre os pais.

\section{Introduction}

Congenital anomalies (CAs) are among the main causes of death in children under 5 years of age. ${ }^{1}$ It is estimated that between 3 and $7 \%$ of children are born with birth defects worldwide, ${ }^{2}$ and that $\sim 270,000$ newborns die during the first 28 days of life every year. ${ }^{2,3}$ In developed countries, CA is the leading cause of death in children, while in developing countries, mortality by CA is still not considered a public health problem. ${ }^{4}$ However, with the control of infections and diseases of nutritional deficiency, there is a tendency to reduce infant mortality for these reasons; thus, congenital malformations have become important causes of perinatal mortality in countries such as Brazil. ${ }^{5,6}$ Currently, 60\% of the etiology of CAs in human beings are not elucidated. However, in around 25\% of CAs, the causes seem to be multifactorial, reflecting a complex interaction of known and unknown genetic and environmental factors, including sociocultural, racial, and ethnic variables. ${ }^{7}$ In Brazil, there is a shortage of data on the incidence of CA and the associated maternal risk factors. The absence of comprehensive studies on CAs in Brazil justifies a prospective study case control that aims to describe the frequency of structural CAs and the characteristics of pregnant women to determine possible risk factors associated with the structural CA. The results presented herein can help in the development of strategies to improve the management, genetic counseling, and rehabilitation of patients with CA as well as the taking of public health measures to determine risk factors.

\section{Methods}

This was a prospective, observational, case-control study based on a hospital population. Pregnant women attended at a fetal medicine service in Brazil were analyzed in the period from October 2014 to February 2016.The research ethics committee of the institution approved the research with the number 808.377. Participants who responded to the questions asked during the interview and performed all the prenatal follow-up at the institution were included in the study. The collection of data was obtained through interview of the pregnant women, using a preform that contained personal and family history (maternal age, maternal ethnicity, previous children with CA, CA family history, and consanguinity) data. Data on previous obstetric history (number of previous pregnancies and prior abortions) were also verified. The presence of structural CA and its classification was confirmed by prenatal ultrasound evaluation by a fetal medicine specialist in. After the monitoring of ultrasounds, the pregnant women were categorized in the case or control groups. The case group was made up of pregnant women of fetuses with structural anomalies, and the control group by pregnant women whose fetuses did not have structural abnormalities. The pregnant women in the case group were accompanied by the main researcher in all the consultations performed after the diagnosis of CA. Thus, it was possible to update the information concerning the development of the fetus. The results of childbirth and newborns with structural anomaly were obtained by telephone contact with the pregnant women, in the computerized reports system, and, in the cases of childbirth performed in the hospital where the study was conducted, by consulting the medical file. The data were analyzed through descriptive statistics (average, standard deviation [SD], absolute frequency, relative frequency, median, confidence interval $[\mathrm{CI}]$ ), Chi-squared tests, odds ratio, and the IBM SPSS Statistics for Windows version 22.0 software (IBM Corp., Armonk, NY, USA). Values of $p<0.05$ were considered statistically significant.

\section{Results}

In the investigation period, 357 pregnant women were sent for attendance at the institution. Of these, 62.46\% (223/357) 
190 Frequency of Congenital Anomalies in the Brazilian Midwest Moraes et al.

were pregnant with fetuses with structural anomalies (case group), and 37.54\% (134/357) were pregnant with structurally normal fetuses (control group). The average age of pregnant women in the case group was 25.73 years, and, in the control group, it was 25.39 years. - Table 1 describes the study population in detail.

Table 1 Description of sociodemographic and obstetric data of pregnant women

\begin{tabular}{|c|c|c|c|c|}
\hline \multirow[t]{3}{*}{ Variables } & \multicolumn{4}{|c|}{ Population } \\
\hline & \multicolumn{2}{|c|}{ Case } & \multicolumn{2}{|c|}{ Control } \\
\hline & $\mathbf{n}$ & $\%$ & $\mathbf{n}$ & $\%$ \\
\hline \multicolumn{5}{|l|}{ Maternal age } \\
\hline$\leq 18$ & 32 & $14.34 \%$ & 19 & $14.18 \%$ \\
\hline $19-24$ & 70 & $31.40 \%$ & 46 & $34.33 \%$ \\
\hline $25-30$ & 69 & $30.94 \%$ & 34 & $25.37 \%$ \\
\hline $31-36$ & 41 & $18.39 \%$ & 26 & $19.40 \%$ \\
\hline$\geq 37$ & 11 & $4.93 \%$ & 9 & $6.72 \%$ \\
\hline \multicolumn{5}{|l|}{ Ethnicity } \\
\hline White & 46 & $20.62 \%$ & 45 & $33.58 \%$ \\
\hline Brown & 128 & $57.40 \%$ & 62 & $46.27 \%$ \\
\hline Black & 45 & $20.20 \%$ & 27 & $20.15 \%$ \\
\hline Indigenous & 4 & $1.80 \%$ & 0 & - \\
\hline \multicolumn{5}{|l|}{ Nr. of gestations } \\
\hline Primigravida & 92 & $41.26 \%$ & 46 & $34.33 \%$ \\
\hline Multigravida & 131 & $58.74 \%$ & 88 & $65.67 \%$ \\
\hline One previous gestation & 68 & $51.91 \%$ & 42 & $47.73 \%$ \\
\hline Two previous gestations & 38 & $29.00 \%$ & 33 & $37.50 \%$ \\
\hline $\begin{array}{l}\geq \text { Three previous } \\
\text { gestations }\end{array}$ & 25 & $19.09 \%$ & 13 & $14.77 \%$ \\
\hline \multicolumn{5}{|l|}{ History of abortion } \\
\hline No & 180 & $80.72 \%$ & 120 & $89.55 \%$ \\
\hline Yes & 43 & $19.28 \%$ & 14 & $10.45 \%$ \\
\hline Previous gestation & 12 & $27.91 \%$ & 5 & $35.72 \%$ \\
\hline $\begin{array}{l}\text { In one of two previous } \\
\text { pregnancies }\end{array}$ & 18 & $41.86 \%$ & 2 & $14.28 \%$ \\
\hline $\begin{array}{l}\text { In one of } \geq \text { three } \\
\text { previous pregnancies }\end{array}$ & 13 & $30.23 \%$ & 7 & $50.00 \%$ \\
\hline \multicolumn{5}{|l|}{ Children with CA } \\
\hline No & 205 & $91.93 \%$ & 131 & $97.76 \%$ \\
\hline Yes & 18 & $8.07 \%$ & 3 & $2.24 \%$ \\
\hline Previous gestation & 2 & $11.11 \%$ & 2 & $66.67 \%$ \\
\hline $\begin{array}{l}\text { In one of two } \\
\text { previous pregnancies }\end{array}$ & 10 & $55.56 \%$ & 0 & - \\
\hline $\begin{array}{l}\text { In one of } \geq \text { three } \\
\text { previous pregnancies }\end{array}$ & 6 & $33.33 \%$ & 1 & $33.33 \%$ \\
\hline \multicolumn{5}{|l|}{ Family history of CA } \\
\hline No & 148 & $66.37 \%$ & 124 & $91.94 \%$ \\
\hline Yes & 75 & $33.63 \%$ & 10 & $8.06 \%$ \\
\hline Parents with CA & 7 & $9.33 \%$ & 1 & $10.00 \%$ \\
\hline
\end{tabular}

Table 1 (Continued)

\begin{tabular}{lllll}
\hline Variables & \multicolumn{3}{l}{ Population } \\
\cline { 2 - 5 } & \multicolumn{2}{l}{ Case } & \multicolumn{3}{l}{ Control } \\
\cline { 2 - 5 } & $\mathbf{n}$ & $\%$ & $\mathbf{n}$ & $\%$ \\
\hline $\begin{array}{l}\text { Brothers or grandmothers } \\
\text { with CA }\end{array}$ & 23 & $30.67 \%$ & 4 & $40.00 \%$ \\
$\begin{array}{l}\text { Uncles and grandmothers } \\
\text { with CA }\end{array}$ & 10 & $13.33 \%$ & 0 & - \\
$\begin{array}{l}\text { Uncles, grandmothers, } \\
\text { and cousins with CA }\end{array}$ & 22 & $29.33 \%$ & 5 & $50.00 \%$ \\
$\begin{array}{l}\text { CA in several relatives } \\
\text { Consanguinity }\end{array}$ & 13 & $17.33 \%$ & 0 & - \\
$\quad \begin{array}{lllll}\text { No } \\
\text { Yes }\end{array}$ & 209 & $93.72 \%$ & 132 & $98.51 \%$ \\
Total & 14 & $6.28 \%$ & 2 & $1.49 \%$ \\
\hline
\end{tabular}

Abbreviations: \%, frequency; CA, congenital anomaly; mean, arithmetic mean; $n$, sample.

Table 2 Distribution of main structural congenital anomalies according to topography and type of lesion

\begin{tabular}{lll}
\hline Congenital anomalies & $\mathbf{n}$ & $\%$ \\
\hline Central nervous system & 23 & $33.33 \%$ \\
Hydrocephalus & 16 & $23.20 \%$ \\
Anencephaly & 7 & $10.14 \%$ \\
Meningocele & 23 & $33.33 \%$ \\
Others & 69 & $100 \%$ \\
Total & & \\
Genitourinary system & 20 & $37.73 \%$ \\
Renal dysplasia & 13 & $24.53 \%$ \\
Hydronephrosis & 12 & $22.64 \%$ \\
Pyelectasis & 8 & $15.10 \%$ \\
Others & 53 & $100 \%$ \\
Total & & \\
Multiple anomalies & 13 & $35.14 \%$ \\
Craniofacial and limbs & 9 & $24.32 \%$ \\
Craniofacial and cardiac & 6 & $16.22 \%$ \\
Craniofacial and digestive & 9 & $24.32 \%$ \\
Others & 37 & $100 \%$ \\
Total & &
\end{tabular}

Abbreviations: \%, frequency; $n$, sample.

The most frequently diagnosed CAs were anomalies of the central nervous system (CNS) $(30.94 \% ; n=69)$, followed by anomalies of the genitourinary system (GUSs) $(23.80 \% ; n=53)$, and, finally, by multiple congenital anomalies (MCAs) (16.60\%; $n=37$ ). - Table 2 demonstrates the distribution of major structural CAs, according to topography and type of lesion. In addition, other abnormalities, such as abdominal (8.52\%; $n=19)$, cardiovascular $(6.30 \% ; n=14)$, and lymphatic system (5.82\%; $n=13)$, among others ( $8.02 \% ; n=18)$, were observed. 
Table 3 Distribution of cases of fetal evaluation according to the characteristics of pregnant women attended at a fetal medicine service

\begin{tabular}{|c|c|c|c|c|c|c|c|}
\hline \multirow[t]{3}{*}{ Variables } & \multicolumn{7}{|c|}{ Population } \\
\hline & \multicolumn{2}{|c|}{ Case } & \multicolumn{2}{|c|}{ Control } & \multirow[t]{2}{*}{ OR } & \multirow[t]{2}{*}{$95 \% \mathrm{Cl}$} & \multirow[t]{2}{*}{$p$-value } \\
\hline & $\mathrm{n}$ & $\%$ & $\mathbf{n}$ & $\%$ & & & \\
\hline \multicolumn{8}{|l|}{ Maternal age } \\
\hline$<35$ & 21 & $90.42 \%$ & 12 & $80.96 \%$ & - & $0.50-2.22$ & 0.884 \\
\hline$\geq 35$ & 202 & $90.58 \%$ & 122 & $91.04 \%$ & & & \\
\hline \multicolumn{8}{|c|}{ Nr. of gestations } \\
\hline Primigravida & 92 & $41.26 \%$ & 46 & $34.33 \%$ & - & $0.86-2.10$ & 0.193 \\
\hline Multigravida & 131 & $58.74 \%$ & 88 & $65.67 \%$ & & & \\
\hline \multicolumn{8}{|c|}{ Previous children with CA } \\
\hline Yes & 18 & 8.07 & 3 & $2.24 \%$ & 3.85 & $1.11-13.27$ & 0.022 \\
\hline No & 205 & 91.93 & 131 & $97.76 \%$ & & & \\
\hline \multicolumn{8}{|c|}{ Family history of CA } \\
\hline Yes & 75 & $33.63 \%$ & 10 & $8.06 \%$ & 6.03 & $3.12-12.67$ & $<0.001$ \\
\hline No & 148 & $66.37 \%$ & 124 & $91.94 \%$ & & & \\
\hline \multicolumn{8}{|l|}{ Consanguinity } \\
\hline Yes & 14 & $6.28 \%$ & 2 & $1.49 \%$ & 4.43 & 0.99-19.76 & 0.034 \\
\hline No & 209 & $93.72 \%$ & 132 & $98.51 \%$ & & & \\
\hline Total & 223 & $100 \%$ & 134 & $100 \%$ & & & \\
\hline
\end{tabular}

Abbreviations: \%, frequency; 95\% Cl, 95\% confidence interval; CA, congenital anomaly; n, sample; OR, odds ratio.

When comparing the case group with the control group, the data analysis revealed a statistically significant difference in relation to the CA family history ( $p<0.001, \mathrm{CI}: 3.12-12.67)$, indicating that pregnant women with relatives who have structural CAs have 6.03 more chance of develop fetuses with structural CAs. Patients with previous children with CAs $(p=0.022)$ and consanguinity $(p=0.034)$ also showed a statistically significant difference between the groups ( - Table 3 ).

\section{Discussion}

During the investigation period, a frequency of $62.46 \%$ of pregnant women with fetuses carrying structural anomalies was observed. The CNS, GUS, and MC anomalies were the most frequent ones. Indian studies showed similar results. ${ }^{8-10}$

Differently, other studies report higher frequency of CAs of the cardiovascular system..$^{5,11-13}$ On the other hand, the higher frequency of CNS has been reported in several studies in Iran, ${ }^{14}$ Japan, ${ }^{15}$ Pakistan, ${ }^{16,17}$ China, ${ }^{18}$ Nigeria, ${ }^{19}$ Tanzania, ${ }^{20}$ and India. ${ }^{8-10}$

The etiology of CNS anomalies is multifactor and involves complex interactions between genetic and environmental factors, constituting one of the most common congenital defects. ${ }^{9,21,22}$ Among the anomalies of the CNS observed in this study, hydrocephalus and anencephaly were the most reported changes, which is similar to other studies that also reported hydrocephalus ${ }^{8,14,17,23}$ and the anencephaly $8,15,17,24$ among the most common malformations.

The data in this study indicated that the occurrence of fetal malformation in one or more family members is associ- ated with the development of CAs in the current gestation. Pregnant women who have a family history of CAs are 6.03 times more likely to develop fetuses with some structural anomaly. the literature data already highlighted this association. ${ }^{8,23}$ Correia et $\mathrm{al}^{25}$ revealed that $16 \%$ of families with registered cases of fetal malformations in Portugal had one or more family members with CAs. In addition, studies indicate that some specific CAs, such as those of the kidney and heart, have the potential to aggregate into families. ${ }^{26,27}$

In this study, the pregnant women who have had children with some CA presented 3.85 times more chance of having other children with malformations. These data are similar to the results of Lie et $\mathrm{al}^{28}$ which showed that mothers who already had a child with CA would have a 2.4 times greater risk of having a second gestation affected when compared with a pregnant woman without a history of CA occurrence. Marwah et $\mathrm{al}^{8}$ observed higher frequency of malformations in pregnant women who had already had children with CA. Thus, possibly, there is a strong tendency of recurrence of specific defects in the same family, indicating the persistence of a causal factor.

Regarding consanguinity, it was verified that consanguineous parents presented 4.43 times more chance of having children with anomalies than parents with no degree of kinship. These data are concordant with other studies that show a positive association between CA and consanguineous parents. $8,9,11,23,29$ However, Hatibaruah and Hussain ${ }^{30}$ found no relation between consanguinity and CA, and Neira et $\mathrm{al}^{31}$ did not observe cases of consanguinity among the parents of malformed newborns. 
Maternal age is considered an important parameter in the birth of a fetus with CA and patients aged $<20$ or $>40$ years old may showed increased risk of having children with certain birth defects. ${ }^{32}$ However, in our study, the correlation between maternal age and CA was not evident $(p=0.884)$. Similar to our findings, the study by Francine et al. ${ }^{11}$ et al also did not report the occurrence of this association. Despide, some studies have reported the association of increased maternal age and the occurrence of CA. ${ }^{8,15}$

There are few studies in the literature that evaluate number of pregnancies as a risk factor for the occurrence of CA. Our study found no differences between the occurrence of $A C$ between and multigravida and primigravida. But, we can verify a higher frequency of CA in multigravida and this result is in agreement with other data in the literature. ${ }^{8,16,30}$ While, other studies have reported a higher frequency of CA in primigravida. ${ }^{9,30-33}$ Thus, the data still do not conclude how parity can influence the occurrence of $\mathrm{CA}$.

The differences between studies can be reflected in different racial, ethnic, and social factors in various regions of the world. Other justifications for these variations include the different study methodologies used for sampling, accessibility, and use of advanced diagnostic techniques, which improve the early and correct detection of CAs. ${ }^{14}$

The current study presents some limitations. First of all, the collected data were from a fetal medicine service, and the prevalence showed may be greater than that of the general population. Because genetic tests are not offered by the institution, tests such as karyotype, that could prove the influence of parental genetics in the occurrence of structural CA, were not performed. However, we recognize the importance of such tests. Despite the aforementioned limitations, we emphasize the importance of this work, mainly because it is prospective and because it presents the reality from the midwest of Brazil.

\section{Conclusion}

In the present study's population, a higher frequency of CNS, GUS, and MC anomalies was observed. The maternal risk factors that may have influenced the occurrence of structural CAs were previous children with CA, family history, and consanguinity. The results related here are important for the development of strategies to improve the management, genetic counseling, and rehabilitation of patients with CA as well as for the taking of public health measures for risk factors.

\section{Contributions}

Moraes C. L.: project development, data collection or management, data analysis, and manuscript writing/editing. Melo N. C.: data collection or management, data analysis, and manuscript writing/editing. Amaral W. N.: project development, manuscript writing, and critical review.

\section{Conflicts of Interest}

The authors have no conflicts of interest to declare.

\section{Acknowledgments}

We appreciate the financial support from Coordenação de Aperfeiçoamento de Pessoal de Nível Superior (CAPES) for providing a PhD scholarship for Melo NC. and Moraes CL.

\section{References}

1 Kyu HH, Pinho C, Wagner JA, Brown JC, Bertozzi-Villa A, Charlson FJ, et al; Global Burden of Disease Pediatrics Collaboration. GBD 2013 Collaboration. Global and national burden of diseases and injuries among children and adolescents between 1990 and 2013: findings from the Global Burden of Disease 2013 Study. JAMA Pediatr. 2016; 170(03):267-287. Doi: 10.1001/jamapediatrics.2015.4276

2 Singh G, Sidhu K. Bad obstetric history: a prospective study. Med J Armed Forces India. 2010;66(02):117-120. Doi: 10.1016/S03771237(10)80121-2

3 Sekhobo JP, Druschel CM. An evaluation of congenital malformations surveillance in New York State: an application of Centers for Disease Control and Prevention (CDC) guidelines for evaluating surveillance systems. Public Health Rep. 2001;116(04):296-305. Doi: $10.1093 / \mathrm{phr} / 116.4 .296$

4 Penchaszadeh VB. Preventing congenital anomalies in developing countries. Community Genet. 2002;5(01):61-69. Doi: 10.1159/000 064632

5 Bhide P, Gund P, Kar A. Prevalence of congenital anomalies in an Indian Maternal Cohort: healthcare, prevention, and surveillance implications. PLoS One. 2016;11(11):e0166408. Doi: 10.1371/ journal.pone.0166408

6 Liu L, Johnson HL, Cousens S, Perin J, Scott S, Lawn JE, et al; Child Health Epidemiology Reference Group of WHO and UNICEF. Global, regional, and national causes of child mortality: an updated systematic analysis for 2010 with time trends since 2000. Lancet. 2012; 379(9832):2151-2161. Doi: 10.1016/S0140-6736(12)60560-1

7 Adeboye M, Abdulkadir MB, Adegboye OA, Saka AO, Oladele PD, Oladele DM, et al. A prospective study of spectrum, risk factors and immediate outcome of congenital anomalies in Bida, North Central Nigeria. Ann Med Health Sci Res. 2016;6(06):380-384. Doi: 10.4103/amhsr.amhsr_108_13

8 Marwah S, Sharma S, Kaur H, Gupta M, Goraya SPS. Surveillance of congenital malformations and their possible risk factors in a teaching hospital in Punjab. Int J Reprod Contracept Obstet Gynecol. 2014;3(01):162-167. Doi: 10.5455/2320-1770.ijrcog20140332

9 Sunitha T, Prasoona KR, Kumari TM, Srinadh B, Deepika MLN, Aruna R, Jyothy A. Risk factors for congenital anomalies in high risk pregnant women: a large study from South India. Egypt J Med Hum Genet. 2017;18(01):79-85. Doi: 10.1016/j. ejmhg.2016.04.001

10 Prashar N, Gupta S, Thakur R, Sharma P, Sharma G. A study of incidence of congenital anomalies in newborn: a hospital-based study. Int J Res Med Sci. 2016;4(06):2050-2053. Doi: 10.18203/2320-6012. ijrms20161758

11 Francine R, Pascale S, Aline H. Congenital anomalies: prevalence and risk factors. Univers J Public Health. 2014;2(02):58-63. Doi: 10.13189/ujph.2014.020204

12 Jain SR, Naik JD, Dhakne BR, Prabhu PM, Kamble SV, Mathurkar MP. Pattern of congenital malformations in newborn: a hospitalbased study. Int J Res Med Sci. 2016;4(02):524-528. Doi: 10.18203/2320-6012.ijrms20160308

13 Egbe A, Uppu S, Lee S, Stroustrup A, Ho D, Srivastava S. Congenital malformations in the newborn population: a population study and analysis of the effect of sex and prematurity. Pediatr Neonatol. 2015;56(01):25-30. Doi: 10.1016/j.pedneo. 2014.03.010

14 Mashhadi Abdolahi H, Kargar Maher MH, Afsharnia F, Dastgiri S. Prevalence of congenital anomalies: a community-based study in the northwest of iran. ISRN Pediatr. 2014;2014:920940. Doi: $10.1155 / 2014 / 920940$ 
15 Chen BY, Hwang BF, Guo YL. Epidemiology of congenital anomalies in a population-based birth registry in Taiwan, 2002. J Formos Med Assoc. 2009;108(06):460-468. Doi: 10.1016/S0929-6646 (09)60093-0

16 Hussain S, Asghar I, Sabir MU, Chattha MN, Tarar SH, Mushtaq R. Prevalence and pattern of congenital malformations among neonates in the neonatal unit of a teaching hospital. J Pak Med Assoc. 2014;64(06):629-634

17 Gul F, Jabin M, Khan AS. Frequency of congenital malformations and associated risk factors at Liaqat Memorial Hospital, Kohat. Khyber Med Univ J. 2012;4(03):119-124

18 Zhang YP, Liu XH, Gao SH, Wang JM, Gu YS, Zhang JY, et al. Risk factors for preterm birth in five Maternal and Child Health hospitals in Beijing. PLoS One. 2012;7(12):e52780. Doi: 10.1371/journal.pone.0052780

19 Ekanem B, Bassey IE, Mesembe OE, Eluwa MA, Ekong MB. Incidence of congenital malformation in 2 major hospitals in Rivers state of Nigeria from 1990 to 2003. East Mediterr Health J. 2011; 17(09):701-705

20 Mashuda F, Zuechner A, Chalya PL, Kidenya BR, Manyama M. Pattern and factors associated with congenital anomalies among young infants admitted at Bugando medical centre, Mwanza, Tanzania. BMC Res Notes. 2014;7:195. Doi: 10.1186/1756-0500-7-195

21 Li K, Wahlqvist ML, Li D. Nutrition, one-carbon metabolism and neural tube defects: a review. Nutrients. 2016;8(11):741. Doi: $10.3390 /$ nu8110741

22 Singh N, Kumble Bhat V, Tiwari A, Kodaganur SG, Tontanahal SJ, Sarda A, et al. A homozygous mutation in TRIM36 causes autosomal recessive anencephaly in an Indian family. Hum Mol Genet. 2017;26(06):1104-1114. Doi: 10.1093/hmg/ddx020

23 El Koumi MA, Al Banna EA, Lebda I. Pattern of congenital anomalies in newborn: a hospital-based study. Pediatr Rep. 2013;5(01): e5. Doi: 10.4081/pr.2013.e5

24 Parker SE, Mai CT, Canfield MA, Rickard R, Wang Y, Meyer RE, et al; National Birth Defects Prevention Network. Updated National Birth Prevalence estimates for selected birth defects in the United
States, 2004-2006. Birth Defects Res A Clin Mol Teratol. 2010;88 (12):1008-1016. Doi: 10.1002/bdra.20735

25 Correia S, Machado A, Braz P, Rodrigues AP, Matias-Dias C. Absence of prenatal ultrasound surveillance: Data from the Portuguese congenital anomalies registry. Birth Defects Res A Clin Mol Teratol. 2016;106(06):489-493. Doi: 10.1002/bdra.23530

26 Øyen N, Poulsen G, Boyd HA, Wohlfahrt J, Jensen PKA, Melbye M. Recurrence of congenital heart defects in families. Circulation. 2009; 120(04):295-301. Doi: 10.1161/CIRCULATIONAHA.109.857987

27 Dias T, Sairam S, Kumarasiri S. Ultrasound diagnosis of fetal renal abnormalities. Best Pract Res Clin Obstet Gynaecol. 2014;28(03): 403-415. Doi: 10.1016/j.bpobgyn.2014.01.009

28 Lie RT, Wilcox AJ, Skjaerven R. A population-based study of the risk of recurrence of birth defects. N Engl J Med. 1994;331(01): 1-4. Doi: 10.1056/NEJM199407073310101

29 Tayebi N, Yazdani K, Naghshin N. The prevalence of congenital malformations and its correlation with consanguineous marriages. Oman Med J. 2010;25(01):37-40. Doi: 10.5001/omj.2010.9

30 Hatibaruah A, Hussain SAM. A study on prevalence of birth defects and its association with risk factors in Fakhrudhin Ali Ahmed Medical College and Hospital. J Evid Based Med Health. 2015;2 (30):4336-4343. Doi: $10.18410 / \mathrm{jebmh} / 2015 / 614$

31 Neira FC, Garay RC, Luzuriaga IT, Cañizares JN, Vega LP. Estudio descriptivo: malformaciones congénitas en recién nacidos del Servicio de Neonatología del Hospital "José Carrasco Arteaga". 2012-2014. Rev Méd HJCA. 2015;7(02):128-133

32 Gill SK, Broussard C, Devine O, Green RF, Rasmussen SA, Reefhuis J; National Birth Defects Prevention Study. Association between maternal age and birth defects of unknown etiology: United States, 1997-2007. Birth Defects Res A Clin Mol Teratol. 2012; 94(12):1010-1018. Doi: 10.1002/bdra.23049

33 Fontoura FC, Cardoso MVLML. Association between congenital malformation and neonatal and maternal variables in neonatal units of a Northeast Brazilian city. Texto Contexto Enferm. 2014; 23(04):907-914. Doi: 10.1590/0104-07072014002320013 